\title{
INTERVIEW WITH H. GRAFF \& B. STREET
}

\author{
Ana Maria de Oliveira Galvão* \\ Maria Cristina Soares de Gouvêa** \\ Ana Maria Rabelo Gomes***
}

Universidade Federal de Minas Gerais (FaE/UFMG), Belo Horizonte - MG, Brazil

The following interview took place in August 2014, during the $\mathrm{V}$ International Colloquium for Literacy and Written Culture ( $V$ Colóquio Internacional Letramento e Cultura Escrita), which was sponsored by the Centre for Literacy, Reading and Writing (Centro de Alfabetização, Leitura e Escrita) (CEALE), and by the Post-Graduate Programme in Education of the Universidade Federal de Minas Gerais (UFMG), Brazil.

This historical meeting brought together two of the most influential thinkers from the generation which rekindled the field of studies on oral language and literacy during the second half of the 1970's. During this meeting, Ana Maria de Oliveira Galvão, Maria Cristina Soares de Gouvêa and Ana Maria Rabelo Gomes, professors of History, Psychology and Anthropology of Education, sought to understand the context in which these authors' most important works were created. They generated a debate about current issues which represent a challenge to those in the field, such as academic literacy and the relations between oral language, written culture and indigenous populations.

Harvey Graff is currently an eminent scholar in Literacy Studies at Ohio State University, in the Unites States.

Brian Street is an Emeritus Professor at the University of King's College, London, UK. He is also a Visiting Professor at the Graduate School of Education at the University of Pennsylvania, in the United States.

\footnotetext{
http://dx.doi.org/10.1590/0102-4698156010

"Ana Maria de Oliveira Galvão is an Associated Professor at the Faculdade de Educação of the Universidade Federal de Minas Gerais (UFMG), and holds a PhD degree in Education from the same university. She is also a CNPq researcher. Email: < anamgalvao@uol.com.br > .

"Maria Cristina Soares de Gouvêa is an Associated Professor at the Faculdade de Educação of the Universidade Federal de Minas Gerais (UFMG), where she obtained her PhD degree in History of Education. She is also a CNPq researcher. Email: < crisoares43@yahoo.com.br > .

"**Ana Maria Rabelo Gomes is an Faculdade de Educação of the Universidade Federal de Minas Gerais (UFMG). She holds a PhD degree in Education from the Università de Bologna, Italy. She is also a CNPq researcher. Email: < anagomes.bhz@terra.com.br>.
} 
Ana Galvão: You've developed your inaugural works almost at the same time - the 1970's -, although in different perspectives, historical and anthropological. The results of your works, to the $19^{\text {th }}$ century in Canada [The Literacy Myth: Literacy and Social Structure in the Nineteenth Century $(1979,1991)$, by Harvey J. Graff] or for the 70's in Iran [Literacy in Theory and Practice (1984), by Brian Street], had great impact in the literacy studies' field. Both helped to overcome the first generation of studies, such as Jack Goody and Eric Havelock's works, by putting literacy as a phenomenon that can only be understood in context. Your studies also helped not dichotomize orality and writing and to understand that literacy is not always related to the individual or social progress. In this sense, the concepts of literacy myth and the autonomous versus ideological models have, for scholars who came after you, great relationships. For us, you would be seen then as two leading researchers of a generation that would change the face of literacy studies. How do you see this relationship between your works today? At the time you developed them, did you have this awareness that they were making a revolution in the field of literacy studies? This is our first question.

Harvey Graff: The Literacy Myth was a historical conjuncture. It reflects the coming together of several currents of the post-World War II period, but in particular developments of the 1960's. First of all, it was shaped by my own growing up. I remember very well the politics of the 1960 's. In fact, I have never eaten grapes since I boycotted grapes with Cesar Chavez ${ }^{1}$ in the 1960's. I protested against Vietnam, I marched for civil rights. My teachers, particularly in the university, were very encouraging of crossing different fields of study, of being critical, and by being critical the lasting legacy for me was always asking questions. I was taught that good questions are more important than answers. Answers are temporary. So part of the politics and civil rights struggle was the rediscovery that for many young people schools were failing. They were not taught either a basic literacy or higher levels of abilities to use literacy (or multiple literacies). This is true for many students (in the United States but not only in the U.S.), particularly minority students, but also for students from the middle class as well. So together, the radical politics, the protests and the discovery of the problems in school shaped me and my scholarship. The key people I read in those days were Jonathan $\mathrm{Kozol}^{2}$, and I think his first book, Death at an Early Age, was his best work, long before we were aware of the Cuban style literacy campaigns or the work of Paulo Freire, which was another influence. 
So those things formed one platform. My family was liberal, more or less, so that helped me to begin to form my own judgments. Then I went to graduate school in history. I decided to study in Canada, partly because of the Vietnam War, but I did not know at that point that I would end up studying what was then called the "new social history." It was the effort to reconceive and find sources and methods to understand and to conduct research in ways that include all the people. The people who did not usually find their way into written and printed sources on the shelves of official archives. And my advisor, Michael B. Katz, who had transformed the history of education with his book The Irony of Early School Reform, was doing one of the first quantitative social history projects using census and related routinely-generated sources. Despite its ambiguity, one of the variables on the Canadian census from 1850 asked about literacy. In the census of 1860, one of the questions was: can you read or write? So in my second semester in grad school, my advisor says: "Play around with that data, see if it's useful and where it may lead." Then I went off to read about literacy and major authors. This was 1971, 1972 and Goody's collection Literacy in Traditional Societies (1968) was a new book at the time. For me, what was important about that book is that it had a chapter by a British economic historian, Roger Schofield, on the measurement of literacy. This certainly raised questions. Roger was skeptical of the modernization equation: "there's literacy and then there's industry and then there's literacy and then there's cities and then there's..." Roger raised the questions that led me to think for many years. For example, about the effects on literacy levels from patterns of migration for countryside to cities and the effects of families working in mills. Both could lead to lowering literacy levels. Published work in Europe and North America supported such views, so this led me to more hypothesis and questions. At the same time, the distinguished British historian Lawrence Stone wrote a very influential paper in the journal Past and Present that was pretty much an elegant summary of the triumph of literacy. It was in contrast with people like Edward Thompson, other social, cultural, labor, and working class history were beginning to suggest or argue. So it's the combination of my background, politics of the times, questions about schooling, its purposes, and effects, past and present, and the goals of the new histories. My study and my first two seminar papers, one on urban literacy and one on rural (the rural article did not get into the Literacy Myth book) were completely quantitative. My advisor told me "you can't do a dissertation that is only quantitative. You have to research other sources." So part 
one of The Literacy Myth was mainly quantitative. The beginning and part two were efforts to interpret the American data. To try to get a sense of what schooling was like, I looked at the debate between contemporary $19^{\text {th }}$ century educators and those in the 1960's and 1970's about how do students learn to read best. Do they learn the letters first, do they learn to read by A, B, C. For what was radical in the 1830's was what we call today the whole word method or sometimes "look-see": let's look at the word and the word will form in your head. I later learned that the very good reading teachers use the "eclectic method," whatever works, works. Different kids learn in different ways. So in reading, in studying literature - this is my last comment - as part of my research, I discovered the emphasis in economics about modernization, I discovered how powerful coming out of American sociology is, the effort to think about literacy, to conquer what is seen as backward and alien to "modern" western notions. For American capitalism to take control of the undeveloped world, the third world, we were going to export literacy. And we were going to train teachers, and we were going to sell millions of text books. So, in modernization approaches, communications was an issue. All those things were really becoming more apparent. As I look across a number of fields and my wonderful teachers said "look widely, let your questions lead you". I became very critical of how literacy was taught and used, critical to the point that over the years I meet people who say with great ignorance, "you're anti-literacy", and I say "oh my god, I make my living by reading and writing". When I wrote "The Literacy Myth after 30 years," [Journal of Social History, 43 (Spring, 2010), 635-661], I tried to clarify that literacy myth was accepted because it was partly true, but its ideological power was contradictory. Does that answer your question?

Ana Galvão: Thank you.

Brian Street: Ok, I can come in lots of ways there, but why don't I come in on the history? I found myself reading Harvey, and a book about 1066 onwards [Michael Clanchy, From Memory to Written Record: English, 1066-1307 (1979)]

Harvey Graff: Oh, yeah, that book came out in 1979.

Brian Street: A whole series of historians have provided literacy which located many of the differences in meanings of the term; for instance, until about the $12^{\text {th }}$ century the word literacy in England meant "knowing Latin". It was only a bit later as Clanchy points out (1979) that the word shifted its meaning; until about the $13^{\text {th }}$ 
century, for people who knew Anglo-Saxon, Latin was what counted, he argued. So that was interesting as an anthropologist. There were later studies in the $18^{\text {th }}$ century. One of the studies of $19^{\text {th }}$ century literacy was about the fact that working class people actually were quite engaged with literacy, they knew quite a lot of literacy. One quote I remember was that in parliament in about the 1880's maybe conservative members of parliament said "we must start teaching literacy at school because we got all those working class trade union members learning literacy in a challenging way; if we're not careful, it'll become like French Revolution". So the teaching of literacy in school was very much an ideological move in order to control people. Not to claim expansion or all the things that the literature now claims about giving literacy to the poor and the working class. It was the opposite. "This will enable us to control". And then Harvey's work quoted all this; I was really up with this; it must have been in the early 80's that we got to this. So how did I get to this? Now we go back instead. My first degree was English. I shifted to anthropology and my $\mathrm{PhD}$ was on written texts, on European representations of nonEuropean society in popular fiction. When that was finished, I was in Oxford with people working around these fields, but well aware of the relation between history and anthropology. So if I was going to move on in anthropology, I needed to do field work. I'd been to Iran, so I went back to Iran. I hadn't gone to study literacy, I'd gone to study rural-urban migration, one of the big themes in anthropology at that point, that was 1970. But sitting in this village I found myself observing the kind of literacy practices, I actually had Jack Goody's book with me, a friend had given it to me. And I knew Jack, I used to go to stay with him in Cambridge, my tutor was a friend of his. And the more I sat in this village, where teachers from the city had begun to engage in a kind of complex literacy, the more the stronger version of what Jack Goody had in that book seemed not to fit. So to jump ahead, I got back to Oxford. I didn't stay very long. I popped up to Cambridge and Jack was running a seminar. I joined in, we discussed these things and he said "well, that doesn't seem to fit what I've been finding". In the village where I did field work, Iranian people engaged in what I called commercial literacy, religious literacy, schooled literacy, a whole variety of skills in reading and writing, none of which were recognized from outside, which continued to treat them as "illiterate". The Farsi word ${ }^{3}$ - and it took me a while to understand this - was "bi-savod" which meant without knowledge. "You should come to study their "bi-savod". That's exactly what I did but coming to different conclusions about their "knowing". Sitting 
there with these people, elaborate, sophisticated, complex, in the antique shop, drinking tea, smoking bubble pipes, they would look at the school textbook I'd been learning from, "Farsi, book 3", and they'd say: "school textbooks are so bad, they have no relationship to what we really have to do, the commercial literacy, or if you go the Mecca where the religious practice where there is religious literacy". So all this elaboration and then back in England looking at the literature, and the stories were beginning to work their way around as I say, and there was this particular view of literacy in traditional society. Jack in his piece in it, it seemed to do this what I termed a "great divide". Now, since then - he is still alive [Jack died in 2015] -, I see him occasionally, we met in Paris at a conference. He lives in France. He continually said that he was never as great as I made him sound. But if you look at literacy in traditional society, then the later books - we've discussed this, we've been going through the details - the later books did offer, he claims, a more sophisticated view of understanding literacy than that earlier book of his. So when you start getting into these fields, we have historians now, anthropologists, there's people of different cultures and countries, everyone picking up certain different bits of it. So we want to hold to people just picking up the "Goody" as a "baddy" (laughs) ${ }^{4}$. Brian's opposing Goody is more subtle. I do say all that to my students when they're coming into studying literacy classes, which I do in Philadelphia in the Graduate school of education. I had another class there just the other day, with students there and in King's [King's College, London] where I teach want to move beyond any caricature. But I also want to make a link here, to work through with people, not just as we're doing this moment of time. We also have to think in terms of historical movements and shifts, way back to Anglo-Saxon, but also in Iran, all historical movements there, South Africa - there's quite a lot going on there, there's very much concern there with historical movement. So the history of ethnography, I think, can bring these fields together.

Harvey Graff: I agree. To get back to 1066 [From Memory to Written Record], the book was by Michael Clanchy, a wonderful man. It's based on 30 years of research, reading hundreds of thousands of documents for three centuries. And one of the things that play off what Brian said: he pointed out that not only the formal definition of literacy came from Latin, but the early medieval England was really a multilingual society with French and Anglo-Saxon as well as Latin. And today I show this to some of my students who are studying multilingualism - some of my education students are interested in 
second language studies and some of my students are coming from foreign languages. There's idea that there is a history and dynamic that we have to contend with if we're looking at multilinguality today. And I think it is best when history and anthropology come together. The University of Michigan has been one of the great centers for this. Too often ethnography becomes so overly focused on such a small things, that it really has no context anymore. We need to return to a historical dimension - and sometimes a properly anthropological grounding to ethnography -, historicizing ethnography and thinking about history ethnographically, even though we never had the sources. This is a reflection of what we were talking about in the conference [ $V$ Colóquio Internacional Letramento e Cultura Escrita] yesterday, different ways of reading sources when you don't have the complete sources.

Brian Street: One of the points I made yesterday was with a colleague called David Bloome, who works in Ohio [Ohio State University] and made the point strongly that the study of ethnography is not simply a particular method or skill, it's the epistemological shift. I think that it gets missed sometimes when people, maybe in sociology, linguistics or other disciplines, look at anthropology and look at ethnography only as another skill. They take ethnography as though it was just a narrow skill. Whereas David - and I agree with him - takes an ethnographic perspective as being epistemological recognition of how we understand images of local people's meanings and practices. We apply that to literacy then, so you say to policy makers and people in school contexts "ok, let's find out what people themselves make of reading and writing" and I mentioned today one response is people say they buy the dominant model, they say "I'm not literate". We've experienced this at the University of Pennsylvania when I worked with graduate students moving into, doing a doctorate, and we talked about what literacy skills do you need in order to do this doctorate. The first position from their tutors as well as themselves is "we've already been literates, we've got our degrees, we've got masters, we've done all this, dissertation, so we don't need to worry about that, we need to worry about the theoretical-methodology issues of the research", and then "Bang!". The tutor starts giving them feedback. Is literacy simply reading comments in the margin, maybe to do with argument, often to do with structure, certainly to do with the genre of writing they were engaged with? So we then developed the notion of illiteracies in that context, to say all kinds of features of writing you are required to do as doctorate student and to move on in the system which aren't made explicit. The tutors don't say "here's what 
you have to do as a doctorate student as opposed to as a masters student". And then it gets even more difficult to get to grips with some of all those PowerPoints. Where do people learn how to do that? More, varied literacy practices, which often hide the practical features of this theoretical-methodological shift so as to recognize that everybody engaged in literacy, whether it's the trader in the Karachi Street or PhD student in Philadelphia may need support in moving on with their literacy. We're not simply saying "no need to teach them literacy, they've got it". Rather, we are saying we can help improve and develop, but let's build with what they've got and let's look at what they need. Some women in Uganda might need some further help in keeping lists of objects and the process of them so that when these men challenge them and rip them off, they can say "look, I've got it down in writing". So it becomes an ideological challenge to dominant perspectives. That might be enough, they don't have to go to a literacy class and sit there and do all this formal stuff. Maybe that's enough. In South Africa, some people would say "no, I want to go further, because I want to actually challenge the dominant apartheid ideology". So the point is, when they're involved in education, "which literacies?" becomes the question. Very often, there are hidden literacies that people aren't aware of and very often you can build on the literacies people bring with them and then extend them according to the context.

Harvey Graff: I think there is a shift under way. For many years, it was up to the student, who had to find and develop, consciously or unconsciously, the structure that hid those literacies. The clever students ferret them out. The older more senior graduate students passed them on. Today, and I think partly generationally, but partly in the USA in response to the crisis of jobs, we want to prepare our students better, and our students want to do everything. There's a crisis if you don't have a publication before you look for a job. So I think a small sign is that in the USA there has been a whole bunch of guide books for students. I don't know if you've met Frank Furstenberg ${ }^{5}$, the sociologist, he wrote one a year or two ago. My point here is: those literacies are sometimes learnt consciously, sometimes unconsciously, sometimes you find a guide. That guidebook can be oral or written. It can be passed on from another student. It can be "you gotta learn this book". In psychology, there is the American Psychology Association guide, in modern languages and literature, the Modern Language Association has a guide, you have to almost memorize it. History and anthropology have quite the same formalization. But when we 
apply this to other levels, of that kind of softening of the dominant model, when you come in from outside and say "okay, I'm not going to one mode or model of instruction, but I'm going to bring two or three models". The real challenge is how we legitimate systems to teach people in different places, because they have to learn enough to begin to ask their own questions about literacy. We need to build systems in all levels for students. For this, technology may be part of an answer but almost never is the answer in and of itself. Yet, so many continue to claim, there is one way rooted in literacy, even though we dress it up with technology, it's still a form, even a soft form, of a dominant ideology and myth. We haven't done a very good job in studying the relationships among those different kind of dominant and supposedly related other factors.

Brian Street: So one concrete example of that. I'm working with doctoral students and I discussed with their colleagues as well about what we mean by the word "essay". So how do you know the genre of writing, and now, I have a discussion with a colleague here about this, he works in psychology and showed me an article he'd written for an English journal, and they almost rejected it. I said "Well, let's have a look at it", and we discussed it, and I said to him "do you like Agatha Christie?" He said "yes", and we discussed that for a while. So for the first 5 or 6 pages he was circling around, not giving too much away, this very narrow view. If you look at $19^{\text {th }}$ century scientific writing, and Charles Darwin is an example that I cited in my research (which was about reading these guides) in Origin of species, for instance, before Agatha Christie, he does say on the last page. And I've talked to people, people in China have that particular genre, should we say, of writing. I'm afraid this US, UK type journal doesn't believe in that, that for very boring reasons historically, takes a narrow view that is so childish. And then, off he went, this colleague. He came back with a new draft, dropped the first 6 pages, sent it off to the journal and of course they accepted it, and he is now on the editorial board. What we've talked about is how can you persuade this editorial board to be a little bit more culturally varied? One more footnote here: this very narrow view of literacy, if you look at $19^{\text {th }}$ century scientific writing, and Charles Darwin is an example. He circles around, he's trying to engage with Lamarck, who had a different theory of evolution anyway. And he does it in a very, might I say, gentlemanly way. Literally unsigned, and it was only recently that we got to this rather narrow little genre. So, one issue with students as we move around these fields is first to recognize "this is what is like", different genres, different power, different ideology. 
Harvey Graff: With serious psychologists on board, we can develop more complicated and appropriate notions about genres in written and other forms of communication. It takes a long time, but I try and teach my students to write in more than one way. Writing American dissertation is not the way to learn to write anything useful (langhs). History, as a discipline, typically expects a book to follow from a doctoral dissertation. We do dissertations for many bad reasons and there are a few good reasons for not writing books. But, there are signs of change. I'm working with some scientists and some people in medicine now about what in the US we generally call writing across the curriculum. The basis of that is that all the students have to take the first and second level of writing this kind of general composition. More and more of us are teaching writing and other forms of communication more explicitly. I teach a second level writing course for honors students and the subtitle is "reading and writing about reading and writing". I make them think hard about what it means to read and to write. I have them do a couple of different papers and research papers, but they're largely based on required reading. So I can make sure they can do at least that reading. This is just one example of many examples. I read early and revised drafts, provide criticism and compare the drafts. Revision is a requirement and an explicit goal. Requirements and practice differ in different fields. In science, for example. I have a colleague - this is a man who's a world expert on insects - he teaches Biology 101 to 800 students who don't want to be there. He makes them read the New York Times every day and in small groups they write science policy [the word he uses is briefs] short position papers. He never thought about using or writing science. He's very concerned about understanding science among American citizens, because most of these students are not going to become biologists. He has also just finished a major research study of the admission test for medical school and even though most biology students do not intend to go to medical school, the nature of that examination has reshaped and ruined how first year biology is taught to almost every student. That represents another way in which one mode of reading, and instruction, can have a major determining effect. This influential practice is not autonomous but it is a dominant and it was not the intention of the medical school people, but, in universities, they have different series of levels of decision making about the curriculum outcome, shaping the nature of reading and writing.

Brian Street: So the same thing, and let me just give one more example, working in another university in London, Queen Mary, 
around these issues. A concrete example of a student who'd done history at A-level ${ }^{6}$ in England and then came to the university and he was combining History and Anthropology. He got an A in his A-level at school. In his first year of the university, he continued to get an A for his essays. I can still see it now, the essay that he wrote for the anthropologist, the tutor using exactly this phrase I refer to all the time "you can't write, get down to the study school center" and the student showed it to me, we discussed what's going on here, "of course I can write, I got A in history". What was going on was that when he tried to do an account of theoretical developments in anthropology using what he thought was a history model, it was a different period and the tutor said "you're falling into an old traditional model of anthropology, forget it now. That model saw progress, earlier periods were backward, primitive, stupid, and now we've moved on, we're modern". And that was the $19^{\text {th }}$ century view in anthropology. One of the first things we try to do with students is say "look, we no longer attempt to answer that question". And that's called "evolutionary theory of progress", and what the tutor thought the student was doing with his historical was an evolutionary account; so it wasn't so much to do with going to the study skills center and learning how to do your verbs, it was actually an epistemological question about the genre and the discipline. And that is the theme, I think, in the academic literacies approach, not just for universities, but for schools too.

Harvey Graff: There's a failure of the anthropology instructor here to say what kind of writing was appropriate for this course. And this anthropology teacher could allow some negotiation. The student says: "I'm a history student. We need to explore the differences and the similarities".

Maria Cristina Gouvêa: In this sense, we can consider that literacy came to an interdisciplinary field about that dialogue between history, anthropology and psychology. Can we define that like this? And do you think that we could teach and research like that today? I was thinking about the dialogue between Clifford Geertz and Robert Darnton during 17 years, sharing the same discipline in the University of Princeton. They really developed a dialogue between the two fields.

Brian Street: Well, more than two. I'm putting social linguistics and I'm being careful here.

Maria Cristina Gouvêa: So do you consider that we can think that literacy came to be an interdisciplinary field and that it will continue like that? 
Brian Street: I think it should be, but how that works in practice is complicated. I'd call it tutors who say "I teach my discipline, my subject. I don't have to teach writing, literacy, that's for school. If these kinds can't do it properly, send them to the clinic to fix them".

Harvey Graff: Where I teach, I'm associated with composition people as well as literature and history people. And I will say: "you have to talk about reading and writing". And they say "no, we won't talk about reading". My very dear friend Deborah Brandt who's one of the best scholars of writing literacy in the US says "too much is said about reading, Harvey. I won't do reading" and I say "Deborah, you are crazy" and she says "maybe". But my new book (Undisciplining Knowledge: Interdisciplinarity in the Twentieth Century (Johns Hopkins University Press, 2015)] is about literacy studies' failure to be interdisciplinary and suggesting ways to change. There's a lot of multidisciplinary, I think. For me, interdisciplinary is not about disciplines, it's about questions and problems and fashioning new and different ways to answer them. But I find too often literacy studies people who say "we're going to take three words from linguistics", but they don't know linguistics. "We're going to borrow words from cognitive psychology", but they don't know cognitive psychology. You have to know, I think, that's my definition, not everybody's, but mine, at least within that particular part of different disciplines, you have to know the basics, and I find people say "I'm taking an anthropological approach to ethnography", but they don't know what that means. The word was current, the word was sexy. Now, Clifford Geertz never understood history and Darnton never understood anthropology, but they had a lot of fun together. And I think that if you look for relationships I think that can be critical. A lot of criticism is negative. But it can also be constructive.

Brian Street: And we go back to square one to ask who said the word literacy. You have to say "what do you mean by it", not assume we'll know where we're going and that's just the word literacy. Start doing with other words, like class, gender, ethnicity.

Harvey Graff: Each of us does need to know what we mean when Brian says literacy, when I say literacy, we both need to be able to say what do we mean.

Brian Street: We don't just, I think, describe, we do try to model what is happening. I would say I would use the word literacy as being at the tip of the iceberg and always recognize what literacy practices it actually refers to. Then I would translate the word in context and always make it about literacy practices rather than just the word literacy. 
Ana Galvão: Your work had great impact in academic circles, but the ideas of literacy myth and autonomous model of literacy are very strong today, it seems that they are stuck in people. Do you think your concepts could be useful to understand and to criticize government programs, school projects, projects with communities that had established very recently contact with literacy, as, in Brazilian case, indigenous?

Ana Gomes: That's a very good question for us and we have this strong policy now that thinks in an autonomous model about literacy that every child has to learn to read and write at the second age. Even if we can criticize this, my personal question is about the other policy that we had to develop for indigenous people because this policy was invading the classroom of indigenous schools and we created another program. So we have Pacto Nacional pela Alfabetização, for all Brazilians with one material, one Portuguese for everybody, and we created Saberes Indígenas na Escola, for a hundred and eighty languages to produce each material for each language but they have similar features, because they are public policies. And it's terrible because we cannot loose the opportunity to ask you about this contradiction. We have to defend the indigenous language, but we use tools that are too similar to the same policies we are trying to confront... So?

Harvey Graff: Can I ask you a question or two about the indigenous languages in Brazil?

Ana Gomes: Yes.

Harvey Graff: Are they all written?

Ana Gomes: Many of them and because of the missionaries. All indigenous languages in Brazil are considered in danger of disappearing. So we have different situations, but there's no strong tradition of written language in many of them. All of them became to be written because of the missionaries or because of school, but today it's a reality.

Harvey Graff: Are there common elements among them? Part of my answer would be to try and build on those common elements. You can't build 180 curricula, but a smaller number. To me, the problem in general when I think internationally is you need to build, and I think there are lessons from history and anthropology here. In my new work, I'm looking at the missionaries again. They have a bad press, but I think some of the missionaries at least did some very interesting things in understanding local cultures and creating alphabets that lasted for centuries. But, more importantly, we need to find ways to teach people to translate from an indigenous language 
or a constructed common indigenous language into Portuguese and move back and forth. I've been thinking particularly in my program LiteracyStudies@OSU about some new concepts. We began a program last year on literacy and translation, and the people most involved are people who do real translation. But I've been thinking about translation within languages. We talked about academic literacies in English. We are really asking our students to translate from writing in a language of history to writing in a lab report in biology. We're teaching them to translate both across different areas but also on different levels as well, and abstractly, to think of ways to promote some students in different curricula to move back and forth. That is a kind of bilingualism, but I think it is more than traditional bilingualism. We need to think about how what's common across languages and the language practices in the sense Brian was talking about. I've also been thinking about how some of the literacy people in the US have been talking about navigating different literacies. Navigation to me seems too much like there is a path, so I'm thinking about negotiation instead. Sometimes negotiation is easy, sometimes it's within ourselves, sometimes is with their parents, sometimes it's with the teachers, but finding ways to help students negotiate among different practices, among different languages, that's my answer.

Brian Street: So, a concrete example that involves this negotiation is that if we look at the latest book title, I think it's called Companion of English Studies', it contains about 30 articles, and it involves exactly that kind of negotiation we talked about. The first move is you can no longer talk about standard English. The world speaks English, few people in this little island over here have a particular version or versions of it. All around the world there are different versions. Now, the ESOL exams they are shifting, but they have tended to try to do this almost autonomous model if you like English. Englishness, with people using it with a big E. So this volume, then, negotiates with people all over the world in different ways of representing the complex varieties that the language varieties of English take. One example is when I was sitting by the table in Singapore with a group of colleagues, people of Chinese background but also people from south India, 4 or 5 different languages, but they were all speaking English. It was not the same English, they were speaking the variety of where they came from. Fine, we're negotiating and we're communicating, we may get lost with some of the words that may not quite work. We had a problem with "refraction" here today actually. So having such a framework we have to say to policy makers. "There 
isn't an answer that suggests this is solid, but rather a framework that says now we can negotiate". Helping us to understand the different meanings, and they're shifting all the time. I think it's a good idea try to learn Portuguese, but not the whole thing in a single package. Instead, you learn aspects of it that are relevant to what you mean to do. That's what people have done in the world all the time. In Africa, there is a complex overlap of language varieties I want to use. When we're working with policy makers we want to say this sort of thing, not just "we have an alternative list of categories fixed for you" but rather it's an epistemological shift. And so in Brazil's case I think if you can find a way of actually being together, people working on indigenous languages, also the "campo" stuff going on, and some of the issues around standard Portuguese and whatever. Allow us to negotiate and discuss which developments are appropriate for which purposes and you get quite a different take. There are bits of Brazil where I thought that would be more the case, I know that governments got a bit more autonomous but I thought there was a little bit more flexibility than we've had in the UK, where we have the national literacy strategy "No child left behind". I thought you had a little bit more flexibility here. That's what I'd be sitting around a table talking to a policy makers about, let's build on this variety of knowledge we get to understanding and take account of indigenous languages, varieties of Portuguese, including the academic literacy thing, include people from rural areas coming in to study. Let's see what happens when we do all of this together.

Harvey Graff: I think we need to tell policy people "let's make Brazil the best in the world in indigenous language education".

Ana Gomes: It takes long, it's a big challenge.

Harvey Graff: The lesson I learned, I have preached complexity my whole life. You cannot teach complexity to policy makers. They see the world in a simple image. I figured this out but I haven't figured out how you put complexity into a simple image. That's one next step.

Brian Street: But what metaphor I have for that, you know, they create this wall that says there's a language, it's build by this, or literacy, but it doesn't quite work. So I was working in Ethiopia with the government, lots of different languages, variety. And so, one metaphor we use is there are cracks in the wall and our current position in terms of policy in the future is we're not getting that much bigger. They're going for cracks in the wall. We're not claiming we "want to change the world or the walls", but in Ethiopia we got 
funded. Uganda, India, just little cracks in the wall, well, because what they're doing doesn't work. So in England the government just... what we're doing doesn't work, it looks as though children in school are doing even worse in literacy, although what they do is sitting down for even longer.

Harvey Graff: And giving them more tests!

Brian Street: Or, "oh, look, here's some cracks in the wall! Look, there are some ways in which a more social practice approach seems to have helped these students a lot". Are you willing to listen? Some say no, but that's about as far as we've got with negotiating with policy makers.

Harvey Graff: It's always “cracks in the wall”.

\author{
$* * *$ \\ Transcrito por Cecília Lana, Clarissa Vieira e Marina Duarte \\ Revisado por Vicente Cardoso Júnior
}

\title{
NOTAS
}

${ }^{1}$ Cesar Estrada Chávez (1927-1998) foi um ativista dos direitos civis e líder sindicalista mexicano.

${ }^{2}$ Jonathan Kozol (1936) é um escritor, educador e ativista norte-americano conhecido por suas publicações sobre educação.

${ }^{3}$ Farsi é a língua persa, falada no Irã, no Afeganistão e por minorias étnicas em outros países árabes. ${ }^{4}$ Jogo de palavras com o sobrenome Goody, em relação ao substantivo "good”, em oposição a "baddy".

${ }^{5}$ Professor de sociologia da Pennsylvania University. Suas pesquisas têm como objeto o estudo de famílias em contextos de vulnerabilidade social, juventude e relações intergeracionais no contexto contemporâneo.

${ }^{6} \mathrm{~A}$-level é a nota máxima obtida nos exames para inserção nas universidades inglesas.

${ }^{7}$ STREET, Brian; LEUNG, Constance (Org.). The Routledge Companion of English Studies. London: Routledge, 2014.

Recebido: 28/10/2015

Aprovado: 06/11/2015

Contato:

Universidade Federal de Minas Gerais (UFMG)

Faculdade de Educação

Av. Antônio Carlos, 6627, Pampulha

Belo Horizonte $|\mathrm{MG}|$ Brasil

CEP 31.270-901 


\section{ERRATA}

1. No artigo "INTERVIEW WITH H. GRAFF \& B. STREET", com número de DOI: <http://dx.doi.org/10.1590/0102-4698156010>, publicado no periódico Educação em Revista. vol.32 no.2, Belo Horizonte, abr./jun. 2016, disponível em: < http://www.scielo.br/ scielo.php?script $=$ sci_arttext\&pid $=$ S0102-46982016000200267\&lng $=$ pt\&nrm $=$ iso\&tlng=en $>$, na linha 1 , página 267 ,

onde se lia:

"INTERVIEW WITH J. GRAFF \& B. STREET"

leia-se:

"INTERVIEW WITH H. GRAFF \& B. STREET"

\section{ERRATUM}

1. In the paper "INTERVIEW WITH H. GRAFF \& B. STREET", with DOI number <http://dx.doi.org/10.1590/0102-4698156010>, published at Educação em Revista. vol. 32 n ${ }^{\circ}$, Belo Horizonte, apr./jun. 2016: <http://www.scielo.br/scielo.php?script=sci_ arttext\&pid=S0102-46982016000100185\&lng=pt\&nrm=iso\&tlng= pt>, on page 267 , line one:

Reads:

"INTERVIEW WITH J. GRAFF \& B. STREET"

Should read:

"INTERVIEW WITH H. GRAFF \& B. STREET" 